\title{
Śniadanie u prezydenta Ratajskiego, czyli co i gdzie jadano w czasie Powszechnej Wystawy Krajowej w Poznaniu
}

\begin{abstract}
Abstrakt: W 1929 r. urządzono w Poznaniu Powszechną Wystawę Krajową, która miała pokazać dorobek odrodzonej Polski. Przez ponad cztery miesiące trwania wystawy Poznań odwiedzały liczne wycieczki krajowe i zagraniczne oraz organizowano wiele kongresów i zjazdów. Obecność tak wielu gości wymagała odpowiedniej aprowizacji. Oficjalne przyjęcia wydawał również prezydent Poznania Cyryl Ratajski. Ich zadaniem było zbliżenie do siebie gości oraz pokazanie Polski i Poznania z jak najlepszej strony. Zachowane menu z tych przyjęć prezentują ówczesną kuchnię polską.
\end{abstract}

Słowa kluczowe: Poznań, Powszechna Wystawa Krajowa, gastronomia.

Abstract: In 1929, the Universal National Exhibition was organized in Poznań, which was to show the achievements of reborn Poland. For over four months of the exhibition, Poznan was visited by numerous domestic and foreign groups of people and held numerous congresses and conventions. The presence of so many guests required adequate provisioning. Poznań Mayor Cyryl Ratajski also hosted official receptions. Their purpose was to bring guests closer together and show Poland and Poznan from the best side. The preserved menu from these parties presents the Polish cuisine of the time.

Key w or ds: Poznań, Universal National Exhibition, gastronomy.

Pomysł Powszechnej Wystawy Krajowej, która miałaby ukazać rozwój i dorobek państwa polskiego po odzyskaniu niepodległości, narodził się jednocześnie w Poznaniu i w środowisku warszawskich architektów. Gdy okazało się, że 
Warszawa nie jest w stanie zrealizować przedsięwzięcia na dziesięciolecie niepodległej Polski, pomysł podchwycił prezydent Poznania Cyryl Ratajski. W ciagu dwóch lat stolica Wielkopolski przygotowała wystawę rozciagająca się na 65 ha, która od maja do września 1929 r. odwiedziło 4,5 mln ludzi z Polski i świata. Pewuka, której głównymi twórcami był prezydent Ratajski i dr Stanisław Wachowiak, przedstawiała dorobek Polski w praktycznie wszystkich możliwych dziedzinach. Większość pawilonów budowano z myśla o ich krótkotrwałej przydatności. Jednak niektóre budynki pozostały po wystawie i na trwałe określiły wygląd dzielnicy Grunwald.

Teren „A” przedstawiał najważniejsze gałęzie przemysłu: ciężki, metalowy, włókienniczy, elektrotechniczny, konfekcyjny, chemiczny, papierowy i inne. $\mathrm{Na}$ terenie „B” znajdowały się pawilony poszczególnych ministerstw, samorządów i innych instytucji państwowych. Dwa największe budynki zostały przeznaczone na Pałac Rządowy (Collegium Chemicum) oraz Pałac Sztuki (Collegium Anatomicum), zaś po zakończeniu Pewuki oddano je Uniwersytetowi Poznańskiemu. Teren „C” obejmował częściowo park Wilsona. To na jego obszarze były pawilony: Polonii za granica, Pracy Kobiet, Palmiarnia, Hut Szkła. Stąd przechodziło się na teren „D”, gdzie ulokowane zostały m.in. bazary, Czerwony Krzyż czy Pawilon Rzemiosła. Największy był teren „E”, gdzie swoje reprezentacyjne pawilony miały wszystkie pozostałe gałęzie przemysłu. Tutaj również znajdowały się Wesołe Miasteczko, które cieszyło się ogromnym powodzeniem, Dancing oraz Arena, gdzie odbywały się zawody i przedstawienia.

Wystawa, zrealizowana $\mathrm{z}$ rozmachem, przyczyniła się do zadłużenia miasta, z którym ówczesne władze nie mogły sobie poradzić, szczególnie że wkrótce nadszedł światowy kryzys gospodarczy. Niemniej jednak trzeba stwierdzić, że osiagnięto ogromny sukces i organizacyjny, i propagandowy. $\mathrm{Z}$ powodu zaniedbania badań nad faktycznymi skutkami Pewuki nie wiadomo do końca, jakie były jej efekty, szczególnie dla poszczególnych wystawców, a zwiedziło wystawę wiele wycieczek z niemal całego świata. Wśród gości, oprócz ogromnej liczby osób prywatnych, przybywali także z oficjalnymi wizytami krajowi i zagraniczni dziennikarze, politycy, przemysłowcy, inżynierowie i członkowie różnych stowarzyszeń i towarzystw. Wystawa stała się także miejscem wielu zlotów i zjazdów. W trakcie każdej wycieczki nie mogło zabraknąć odpowiedniego, oficjalnego przyjęcia - śniadania, obiadu, bankietu lub rautu, stosownie do rangi wydarzenia i pory dnia. Dokumenty zgromadzone w Archiwum Państwowym w Poznaniu - zachowane programy wycieczek, rachunki i jadłospisy - pozwalają zbadać, gdzie i co jedzono podczas Pewuki, w trakcie oficjalnych przyjęć, a tym samym co oferowała kuchnia poznańska końca lat dwudziestych.

Zapewnienie aprowizacji gościom wystawowym oraz ludności Poznania powierzono Izbie Przemysłowo-Handlowej, która winna czuwać nad tym, aby nie zabrakło towarów oraz nie spekulowano cenami. Na terenie wystawy 
zwiedzający mieli do dyspozycji kilka miejsc (w zależności od portfela i gustu), gdzie można było spożyć posiłek. Na przykład restauracja hotelu Polonia przygotowała się na sprostanie najbardziej wybrednym podniebieniom ${ }^{1}$.

Komisarz żywnościowy (w ramach Izby Przemysłowo-Handlowej) ustalił nawet ceny, jakie powinny $\mathrm{w}$ czasie wystawy obowiązywać $\mathrm{w}$ restauracjach w mieście (tabela 1).

Tabela 1. Ceny w restauracjach

\begin{tabular}{|l|c|c|c|c|c|}
\hline \multicolumn{1}{|c|}{ Restauracje } & Śniadanie & Obiad & Kolacja & $\begin{array}{c}\text { Całodzienne } \\
\text { utrzymanie }\end{array}$ & $\begin{array}{c}\text { Kawa lub herbata } \\
\text { z 2 buleczkami } \\
\text { do śniadania }\end{array}$ \\
\cline { 1 - 5 } tzw. obywatelskie & $1,25 \mathrm{zł}$ & $1,50 \mathrm{zl}$ & $2,20 \mathrm{zł}$ & $4,95 \mathrm{zl}$ & \multirow{2}{*}{$1,20 \mathrm{zł}$} \\
\cline { 1 - 5 } pierwszorzędne & $1,50 \mathrm{zł}$ & $2,80 \mathrm{zł}$ & $3 \mathrm{zł}$ & $7,30 \mathrm{zl}$ & \\
\cline { 1 - 4 } luksusowe & $2 \mathrm{zł}$ & $4,50 \mathrm{zł}$ & $6 \mathrm{zl}$ & $12,50 \mathrm{zł}$ & \\
\hline
\end{tabular}

Źródło: S. Waschko, Aprowizacja na P.W.K., w: Powszechna Wystawa Krajowa w Poznaniu w roku 1929. Dzieło zbiorowe pod kierownictwem dr. Stanistawa Wachowiaka prezesa Zarzqdu P.W.K., t. II, Poznań 1930, s. 292.

Inne przywidywano ceny za kawy, herbaty i ciastka w kawiarniach w czasie, gdy nie było koncertów i podczas wydarzeń muzycznych, kiedy to napoje i słodkości miały być nieznacznie droższe ${ }^{2}$. W rzeczywistości nie wszyscy prowadzący restauracje i kawiarnie przestrzegali zarządzeń. Prawdopodobnie działo się tak, ponieważ byli niezadowoleni z dochodów - mniejszych niż się spodziewali i niewspółmiernych do poniesionych wcześniej wydatków na remonty lokali ${ }^{3}$ i zakup produktów ${ }^{4}$.

Przed wystawą zaczęło powstawać wiele lokali restauracyjnych ${ }^{5}$, a ich właściciele liczyli na duże zyski dzięki zwiedzającym nie tylko Pewukę, ale przecież i Poznań. Turyści mieli więc zaprezentowaną bardzo szeroką ofertę gastronomiczna. W przewodniku po Poznaniu, wydanym z okazji Pewuki, polecano kawiarnie i cukiernie: Dobskiego na ul. Fredry, Esplanadę i Grand Café przy pl. Wolności, Fangrata na ul. Ratajczaka (naprzeciwko Biblioteki Uniwersyteckiej, skąd zresztą często zamawiał ciasta Ratusz i gdzie można

1 S. Maciejewski, Aprowizacja Miasta Poznania w czasie Wystawy, „Tygodnik Ilustrowany”, 21 IX 1929, nr 28, s. 8.

${ }^{2}$ S. Waschko, Aprowizacja na P.W.K., w: Powszechna Wystawa Krajowa w Poznaniu w roku 1929. Dzieło zbiorowe pod kierownictwem dr. Stanistawa Wachowiaka prezesa Zarzadu P.W.K., t. II, Poznań 1930, s. 293.

${ }^{3}$ Ibidem, s. 295.

${ }^{4}$ P. Litewka, Powszechna Wystawa Krajowa, część pierwsza, (16 maja - 30 września 1929), „Kronika Miasta Poznania” 1979, nr 2, s. 48; idem, Powszechna Wystawa Krajowa (16 maja30 września 1929). Dokończenie, „Kronika Miasta Poznania” 1979, nr 3, s. 9.

${ }^{5}$ W. Czarnecki, To byt tė mój Poznań. Wspomnienia architekta miejskiego z lat 1925-1939, wybór i oprac. J. Dembski, Poznań 1987, s. 58. 
było również napić się kawy i alkoholu), Magnolia przy ul. Głogowskiej, Pfitznera na Starym Rynku, Warszawiankę przy Alejach Marcinkowskiego i Ziemiańska przy ul. 27 Grudnia?

Wspomnienia z tamtych czasów potwierdzaja, że popularnością cieszyła się kawiarnia Dobskiego, a spośród restauracji wymieniano wytworną Hungarię i Palais Royal przy pl. Wolności ${ }^{8}$. Na Kantaka mieścił się Tunel Europejski reklamowany jako największa restauracja obywatelska, ze smaczna kuchnia i przystępnymi cenami. Na rogu Zwierzynieckiej i Jasnej znajdowała się restauracja-kawiarnia-winiarnia Bristol, gdzie podawano piwa: Prajzdrój Pilzneński, Żywiecki i Kobylepolskie. Przewodniki wskazuja również Continental na św. Marcinie, Dworcową na Dworcu Głównym, Pod Strzechą i Wielkopolankę na pl. Wolności czy „tanią i dobra kuchnię” przy ogrodzie zoologicznym ${ }^{9}$. Nie sposób wymienić tutaj wszystkich lokali, warto jednak nieco więcej napisać o tych, do których udawano się na najbardziej eleganckie przyjęcia.

Restauracja Palais Royal mieściła się obok Biblioteki Raczyńskich, przy pl. Wolności 19a, w wolno stojącym budynku, do którego dochodziło się przez bramę pod trzema łukami. Uchodziła za najwytworniejszą w całym Poznaniu, a już na pewno przy samym placu, gdzie znajdowało się wiele restauracji i kawiarni. Jej wnętrze było niemal pałacowe, ze złoconymi meblami. Odbywały się tam bale, dancingi, przyjęcia, a nawet pokazy mody ${ }^{10}$.

Nieopodal Palais Royal znajdował się hotel Bazar (na skrzyżowaniu Alei Marcinkowskiego 10 i ul. Nowej 7/8), którego restauracja mogła śmiało konkurować z powyżej omawiana. Słynna była szczególnie winiarnia, należąca do najlepiej zaopatrzonych w Polsce. W pięknej Sali Białej odbywały się obiady oraz rauty. Pewuka nie wpłynęła na finanse Bazaru, swoje piętno odcisnął na nim za to późniejszy kryzys gospodarczy ${ }^{11}$.

Na Pewuce również nie brakowało miejsc, gdzie można by odpocząć i posilić się. Organizatorzy starali się tak rozmieścić restauracje i kawiarnie, aby z każdego miejsca można było łatwo dotrzeć na posiłek. We wspomnieniach zachowała się treść jednego z plakatów zachęcających do odwiedzania lokali gastronomicznych:

${ }^{6}$ Restauracja ta, według projektu Władysława Czarneckiego, wybudowana w 1925 r., posiadała piękna, przestronną salę z kolumnami. Nie jest wymieniana jednak jako restauracja wystawowa w przewodniku po samej wystawie, ale z pewnością wielu gości właśnie tam przychodziło na obiad.

${ }^{7}$ Poznań w roku Powszechnej Wystawy Krajowej. Przewodnik po mieście, jego zabytkach i muzeach z trójbarwnym planem miasta i 15 ilustracjami, oprac. H. Szczerbowski, Poznań 1929, s. 12.

8 B. Danielewski, Pewuka, w: Poznańskie wspominki z lat 1918-1939, red. T. Kraszewski, T. Świtała, Poznań 1973, s. 152.

${ }_{9}$ Poznań w roku Powszechnej Wystawy Krajowej..., s. 11-12.

${ }^{10}$ W. Karolczak, Spacerkiem po Plajcie, „Kronika Miasta Poznania «Plac Wolności»” 2014, nr 4, s. 60 .

11 A.M. Skałkowski, Bazar w nowej Polsce (1921-1938), „Kronika Miasta Poznania «Bazar»” 2008 , nr 2, s. 58. 
Przed Tobą 3/4 Wystawy.

Chcesz wiele zobaczyć, wszystko zapamiętać; wobec tylu nowych wrażeń nie zauważyłeś, że Twój organizm już sygnalizował ważną nowinę „chcę jeść”.

Zwiedzając tak dalej „na głodno”, wnet zmęczysz się, nerwowo osłabniesz. Im później spostrzeżesz owe sygnały - tem gorzej; osłabienia bólu głowy, ogólnego zniechęcenia nie usunie spóźniony „obfity obiadek”; a przeciwnie, po nim będziesz bardziej ociężały. Twój budżet pozwolił na przyjazd i pobyt w Poznaniu; wydaj jeszcze małą kwotę, aby zwiedzanie było pożyteczniejsze.

Kup w kiosku przed „Uzdrowiskami”

Paszteciki ${ }^{12}$ i pierożki

„Witamit”

Przyrządzone wyłącznie na maśle $\mathrm{z}$ wyborowych surowców, zdrowe i tanie ${ }^{13}$.

Centralną restauracją wystawy był Dwór Huggera przy ul. Śniadeckich 12, w zaadaptowanej na potrzeby restauracyjne dawnej słodowni browaru. W suterenach mieścił się bar na 250 osób i piwiarnia w stylu zakopiańskim na 1200 , gdzie można było zjeść niedrogi (1,20-1,50 zł) obiad. Na parterze znajdowały się wielkie sale restauracyjne. W hallu mogło usiasść 120 osób, w sali restauracyjnej - 620, a w sali bankietowej - 1000, gdzie po przedstawieniach teatralnych odbywały się dancing i kabaret. Sala teatralna na 1400 miejsc, gdzie działał teatr Rewja, była na pierwszym piętrze. Przedstawienia odbywały się o godz. 17.15 i $22.00^{14}$ i podobno cieszyły się dużym powodzeniem ${ }^{15}$. Restauracja mogła naraz pomieścić od 2500 do 3000 gości, a w ciagu dnia nawet 6000 . Była samowystarczalna, ponieważ miała własna rzeźnię, lodownię i maszynę do mycia naczyń (!). W ogrodzie urządzono kawiarnię i podawano głównie kawę i zimne napoje ${ }^{16}$. Miejsce to z pewnościa cieszyło się dużą popularnością. Oferowano niedrogie posiłki, a jednocześnie istniała tam możliwość zorganizowania dużego i eleganckiego przyjęcia.

Lokalem, który miał odciążyć nieco centralną restaurację, był Dancing, usytuowany obok Areny i Wesołego Miasteczka, posiadał on jednak dużo mniej oficjalny charakter. Mógł pomieścić ponad 600 osób i był w istocie restauracją-winiarnią z dancingiem i kabaretem. Okazał się jednak bardzo deficytowym przedsięwzięciem, ponieważ przyniósł tylko 40 tys. dochodu wobec 220 tys., które kosztowała budowa ${ }^{17}$.

12 Paszteciki musiały być bardzo popularne w Polsce przedwojennej, a nawet na przełomie XIX i XX w. W ówczesnych książkach kucharskich podawano na nie wiele przepisów. Podstawą było ciasto kruche, z różnymi nadzieniami, które podłużnie zwijano i wrzucano następnie na głęboki, rozgrzany tłuszcz.

${ }_{13}$ B. Danielewski, op. cit., s. 162.

${ }^{14}$ Przewodnik po Wystawie. Powszechna Wystawa Krajowa w 1929 roku w Poznaniu, Poznań 1929, s. 48, 50, 130. Bogdan Danielewski podaje, że przedstawienia były nie o 17.15 , ale o 19.30. B. Danielewski, op. cit., s. 163.

${ }^{15}$ Ł. Kempisty, Przedsiębiorstwa, w: Powszechna Wystawa Krajowa..., s. 208.

16 Ibidem.

${ }^{17}$ Ibidem, s. 208-209. 
Restauracja Belweder w budynku administracji wystawy przy ul. Głogowskiej funkcjonowała już kilka lat wcześniej przed tym przedsięwzięciem. Mogła przyjąć dziennie 2000 osób. Była bardzo elegancka, posiadała dużą salę i taras, z którego oglądano tereny wystawy ${ }^{18}$.

W krytym przejściu między Halą Włókienniczą a dziedzińcem był browar Braci Koteckich, mogący przyjąc 450 gości. Przy Pawilonie Przemysłu Metalowego mieściła się piwiarnia Zjednoczonych Browarów Warszawskich Haberbusch i Schiele, gdzie oprócz piwa serwowano również zimne i ciepłe zakąski. Na krytym tarasie Pawilonu Ministerstwa Poczt i Telegrafów, w miejscu, którego nie można było zapełnić eksponatami, uruchomiono restaurację, która cieszyła się sporym powodzeniem, przynosząc duże dochody. Z kolei na terenie „E”, gdzie prezentowano przemysł, wzdłuż głównej alei ustawiono pawilon Browaru Okocimskiego, który mógł dziennie wydać 1000 obiadów. Na tym samym terenie, przy Wesołym Miasteczku, znajdowała się paszteciarnia, organizatorzy wystawy przyznali jednak, że przedsięwzięcie to zakończyło działalność z dużą strata. Inne restauracje były także w Pawilonie Ogrodnictwa oraz w tzw. gospodzie przeznaczonej dla mniej zamożnych wycieczek ${ }^{19}$.

Aby zapewnić wyżywienie (a czasem także, by wykorzystać wolna przestrzeń) zwiedzajacym tereny oddalone od większych restauracji, organizatorzy urządzili w większych pawilonach bufety z zimnymi i ciepłymi przekaskami oraz automaty bufetowe, w których po wrzuceniu monety otrzymywało się m.in. piwo i bułki z wędliną ${ }^{20}$.

$\mathrm{Na}$ wystawie funkcjonowały również kawiarnie i cukiernia Fangrata. Ta ostatnia zlokalizowana była na tarasie Palmiarni. Jedna z kawiarni znajdowała się nieopodal - na tarasie Pawilonu Pracy Kobiet. Cieszyła się ona bardzo dużą popularnością i rozciagał się z niej piękny widok na Palmiarnię, park Wilsona i bardzo ciekawy architektonicznie Pawilon Hut Szkła. Dwie inne kawiarnie znajdowały się w Pawilonie Produkcji Roślinnej i przy Pawilonie Ziemianek i Włościanek ${ }^{21}$.

Nie wiadomo, co podawano w restauracjach i bufetach na terenie wystawy, przeznaczonych dla mniej zamożnej klienteli. Można się tylko domyślać na podstawie tego, co wiemy o lokalach z przełomu XIX i XX w. i popularnych potrawach - były to mięso z kotła, zrazy, sztuka mięsa, kiełbasa czy ryby ${ }^{22}$, popularne nie tylko na ziemiańskich stołach, ale i mniej zamożnych ${ }^{23}$. Poza

18 Ibidem, s. 209.

19 Ibidem, s. 209-210.

${ }^{20}$ Ibidem, s. 211. Urządzenie takie nie było novum, jak mogłoby się wydawać. W Poznaniu pierwsza „automatyczną restaurację” otworzono naprzeciwko Teatru Polskiego w $1903 \mathrm{r}$. W. Karolczak, Coś dla podniebienia, czyli specjalności kulinarne w lokalach poznańskich na przełomie XIX i XX wieku, „Kronika Miasta Poznania «Do stołu podano»” 2003, nr 4, s. 157.

${ }^{21}$ Aprowizacja, „Echo Powszechnej Wystawy Krajowej”, 8 IV 1929, s. 152.

${ }^{22}$ W. Karolczak, Coś dla podniebienia..., s. 152-153.

${ }^{23}$ M. Łozińska, Smaki dwudziestolecia. Zwyczaje kulinarne, bale i bankiety, Warszawa 2011, s. 14. 
tym mogły to być flaki ${ }^{24}$, bigos czy fasolka po bretońsku, które podawano w barach szybkiej obsługi ${ }^{25}$. Można się domyślać, że oprócz typowo „barowych” dań menu było podobne do tego, które przygotowywano w domach w miastach i na wsiach, gdzie podstawę posiłku stanowiła zupa - rosól, barszcz zabielany, jarzynowa czy krupnik. Do mięsa na drugie danie podawano tłuczone ziemniaki i gotowane jarzyny. Poza tym popularne były pierogi ruskie z kasza gryczaną i serem, placki ziemniaczane czy zsiadłe mleko z kaszą gryczaną ${ }^{26}$.

Prezydent Ratajski wydawał przyjęcia wiele razy w trakcie przyjazdów ważnych gości. O 13.00 serwowano śniadanie, a ok. 19.00-20.00 - obiad. Do dzisiaj wedle protokołu dyplomatycznego sa to przyjęcia zasiadane, raut natomiast to przyjęcie stojące, gdzie podaje się tylko alkohol i zakaski. Magistrat, a w szczególności dyrektor biur - Józef Walkowiak czuwał nad sprawną i drobiazgową organizacja. Ustalano więc listę gości, rozsyłano za każdym razem eleganckie zaproszenie, odnotowywano, kto się pojawi, planowano menu oraz wyznaczano woźnych, którzy mieli służbę w poszczególnych pomieszczeniach (np. w korytarzach, Złotej Sali, pokoju burmistrzów, czytelni, bibliotece) przy konkretnych czynnościach, jak liczenie gości, wskazywanie garderoby, nalewanie wody sodowej i alkoholu, otwieranie wina, podawanie papierosów ${ }^{27}$. Posiłek spożywano zazwyczaj w Złotej Sali ratusza, przedtem jednak był zimny bufet (zakaski) w bibliotece lub Sali Odrodzenia. Zasiadano przy podłużnym stole lub ustawionym w literę „U”. Oczywiście wcześniej planowano odpowiednie usadzenie gości. Zachowały się zresztą projekty z oznaczeniami zaproszonych osób przy stole.

$\mathrm{Na}$ tak uroczyste okazje szykowane były sztućce $\mathrm{z}$ herbem Poznania i elegancka porcelana z Chodzieży lub firmy Rosenthal. Dyrekcja ogrodów miejskich przygotowywała harmonizujacca ze sobą kwiatową dekorację na stoły i do sal28. Na przyjęciach przygrywała zazwyczaj orkiestra i obowiązywał strój wizytowy lub wieczorowy (frak). Na zaproszeniu proszono o odpowiedź i informowano, że trzeba będzie pokazać je przy wejściu. Menu przygotowywała Piwnica Ratuszowa - restauracja znajdująca się w przyziemiu poznańskiego ratusza. Zdarzało się, że restauracja proponowała różne warianty menu w zależności od liczby gości. Podczas Pewuki prezydent organizował przyjęcia nie tylko w ratuszu, choć tam miało to miejsce najczęściej, ale również w restauracji

${ }^{24}$ Popularną i najsmaczniejszą podobno odmianą flaków były flaki garnuszkowe, które przyrządzano według dziewiętnastowiecznej receptury. Do garnka wlewano flaki i pulpety, posypywano parmezanem, zalewano masłem smażonym $\mathrm{z}$ bułką tartą $\mathrm{i} \mathrm{w}$ takiej postaci zapiekano w piecu. Później można je było doprawić papryka, imbirem lub majerankiem. Ibidem, s. 90.

${ }^{25}$ Ibidem, s. 90.

${ }^{26}$ Ibidem, s. 18, 92.

${ }^{27}$ Archiwum Państwowe w Poznaniu (dalej: APP), Akta Miasta Poznania (dalej: AmP), 2470, Wycieczka Korpusu Oficerskiego i Kadetów Włoskiej Szkoły Marynarki Wojennej z Livorno, 31 VII 1929.

28 S. Leitgeber, Rauty u prezydenta, „Kronika Miasta Poznania” 1996, nr 4, s. 113. 
hotelu Polonia. Dzięki zachowanym menu przyjęć organizowanych przez prezydenta Ratajskiego można odtworzyć, co, gdzie i jak wówczas podawano.

Tabela 2. Szczegóły przyjęć wydanych przez prezydenta miasta Poznania

\begin{tabular}{|c|c|c|c|}
\hline Data & Przyjęcie & Szczegóły & Menu \\
\hline $\begin{array}{l}21 \mathrm{~V} \\
1929^{29}\end{array}$ & $\begin{array}{l}\text { Śniadanie } \\
\text { z okazji przyjęcia kół } \\
\text { śpiewaczych o godz. } \\
13.30\end{array}$ & $\begin{array}{l}\text { Przyjęcie na ok. } 100 \text { osób, } \\
\text { w ratuszu, przygotowała } \\
\text { Piwnica Ratuszowa }\end{array}$ & $\begin{array}{l}\text { Zakaski i wódki } \\
\text { Zupa maderowa }^{30} \\
\text { Sandacz po parysku } \\
\text { Polędwica po angielsku } \\
\text { garnirowana }{ }^{32} \\
\text { Owoce mrożone w galarecie } \\
\text { Kawa }\end{array}$ \\
\hline $\begin{array}{l}31 \mathrm{~V} \\
1929^{33}\end{array}$ & $\begin{array}{l}\text { Śniadanie z okazji } \\
\text { przyjazdu wycieczki } \\
\text { Zjednoczenia Polskiego } \\
\text { Rzymsko-Katolickiego } \\
\text { w Ameryce }\end{array}$ & $\begin{array}{l}\text { Przyjęcie ratuszu w Sali } \\
\text { Odrodzenia, przygotowała } \\
\text { Piwnica Ratuszowa }\end{array}$ & $\begin{array}{l}\text { Barszcz w filiżankach } \\
\text { Sałatka włoska } \\
\text { Kanapki } \\
\text { Sandacz w majonezie } \\
\text { Węgorz w galarecie } \\
\text { Węgorz wędzony } \\
\text { Ragoût fin }{ }^{34} \\
\text { Bigos } \\
\text { Szynka gotowana san remo } \\
\text { Kawa, herbata, woda sodowa } \\
\text { Alkohol: koniak, wódka } \\
\text { Wyborowa, Monastyk }\end{array}$ \\
\hline $\begin{array}{l}11 \mathrm{VI} \\
1929^{35}\end{array}$ & $\begin{array}{l}\text { Śniadanie z okazji } \\
\text { przyjazdu ambasadora } \\
\text { Noulensa z wycieczka } \\
\text { przemysłowców } \\
\text { francuskich o godz. } \\
13.30\end{array}$ & $\begin{array}{l}\text { Przyjęcie w ratuszu na } \\
52 \text { osoby w Sali Odrodzenia } \\
\text { i Sali Złotej, przemówienie } \\
\text { Cyryla Ratajskiego } \\
\text { po francusku, menu } \\
\text { przygotowała Piwnica } \\
\text { Ratuszowa, strój wizytowy }\end{array}$ & $\begin{array}{l}\text { Zakasski i wódki } \\
\text { Rosół princesse } \\
\text { Łosoś z wody, sos musseline }{ }^{36} \\
\text { Comber cielęcy, sałata zielona } \\
\text { i kompot } \\
\text { Bomba piklera (lody) } \\
\text { Kawa }\end{array}$ \\
\hline $\begin{array}{l}13 \mathrm{VI} \\
1929^{37}\end{array}$ & $\begin{array}{l}\text { Śniadanie } \\
\text { z okazji przyjazdu } \\
\text { przemysłowców } \\
\text { greckich o godz. } 13.30\end{array}$ & $\begin{array}{l}\text { Przyjęcie na ok. } 30 \text { osób } \\
\text { w hotelu Polonia, strój } \\
\text { wizytowy, koszt śniadania } \\
\text { 1769,36 zł }\end{array}$ & $\begin{array}{l}\text { Zakąski i wódki } \\
\text { Barszcz, diablotki }^{38} \\
\text { Sandacz po polsku }^{39} \\
\text { Kurczęta po polsku }{ }^{40}, \text { kompot } \\
\text { Puchar Blobier } \\
\text { Kawa } \\
\text { Likiery }\end{array}$ \\
\hline
\end{tabular}

${ }_{29}$ APP, AmP, 2459, Wszechsłowiański Zjazd Śpiewaczy w Poznaniu.

${ }^{30}$ Być może chodzi o zupę ogonową $\mathrm{z}$ dodatkiem madery.

31 Sandacz duszony w winie, zapiekany pod parmezanem z bułeczkami z ciasta parzonego. M. Norkowska, Najnowsza kuchnia wytworna i gospodarska, Warszawa-Kraków 1903, s. 93.

${ }^{32}$ Polędwica marynowana w oliwie z włoszczyzna, pieczona następnie w brytfance $\mathrm{z}$ masłem lub na rożnie. Podawana z groszkiem, marchewka, kalafiorem, ziemniakami. Ibidem, s. 125.

${ }^{33}$ APP, AmP, 2456, Kongresy i zjazdy, k. 73.

${ }_{34}$ Mięso, najczęściej wołowe, duszone $\mathrm{z}$ warzywami w gęstym sosie.

35 APP, AmP, 2461, Wycieczka przemysłowców francuskich, 11 VI 1929.

${ }^{36}$ Sos musseline, czyli muślinowy na bazie żółtek, soku z cytryny, masła i śmietany.

${ }_{37}$ APP, AmP, 2462, Wycieczka grecka.

${ }^{38}$ Grzanki z ciasta francuskiego, w formie pałeczek z parmezanem.

${ }^{39}$ Pieczony sandacz podany z posiekanym, ugotowanym jajkiem.

${ }^{40}$ Kurczęta faszerowane wątróbka. 


\begin{tabular}{|c|c|c|c|}
\hline Data & Przyjęcie & Szczegóły & Menu \\
\hline $\begin{array}{l}30 \mathrm{VI} \\
1929^{41}\end{array}$ & $\begin{array}{l}\text { Śniadanie wydane } \\
\text { na cześć uczestników } \\
\text { wycieczki } \\
\text { korespondentów pism } \\
\text { zagranicznych }\end{array}$ & $\begin{array}{l}\text { Przyjęcie na } 70 \text { osób, } \\
\text { w Sali Złotej w ratuszu, } \\
\text { strój wizytowy, menu } \\
\text { przygotowała Piwnica } \\
\text { Ratuszowa }\end{array}$ & $\begin{array}{l}\text { Zakaski i wódki } \\
\text { Zupa rakowa }{ }^{42} \\
\text { Łosoś sos musseline } \\
\text { Szparagi w maśle } \\
\text { Kurczęta, sałata zielona } \\
\text { i kompot } \\
\text { Lody mieszane } \\
\text { Kawa } \\
\text { Likiery }\end{array}$ \\
\hline $\begin{array}{l}4 \mathrm{VII} \\
1929^{43}\end{array}$ & $\begin{array}{l}\text { Śniadanie z okazji } \\
\text { Zjazdu Chemików } \\
\text { w ratuszu o godz. } 14.00\end{array}$ & $\begin{array}{l}\text { Przyjęcie na } 50 \text { osób, } \\
\text { w Sali Złotej w ratuszu, } \\
\text { strój wizytowy, menu } \\
\text { przygotowała Piwnica } \\
\text { Ratuszowa }\end{array}$ & $\begin{array}{l}\text { Zakaski i wódki } \\
\text { Zupa maderowa } \\
\text { Lin } \\
\text { Szparagi w maśle } \\
\text { Pieczeń sarnia z sałata, } \\
\text { kompot } \\
\text { Lody mieszane }\end{array}$ \\
\hline $\begin{array}{l}2 \text { VIII } \\
1929^{44}\end{array}$ & $\begin{array}{l}\text { Przyjęcie z okazji } \\
\text { pobytu Generalnego } \\
\text { Sekretarza Ligi } \\
\text { Narodów p. Giacomo } \\
\text { Paulucci di Calboli } \\
\text { Barone z żoną }\end{array}$ & $\begin{array}{l}\text { Około } 17 \text { osób, } \\
\text { przygotowała restauracja } \\
\text { hotelu Polonia }\end{array}$ & $\begin{array}{l}\text { Wódki, koniak, zakaski } \\
\text { Zupa pomidorowa } \\
\text { z pasztecikami } \\
\text { Łosoś z rusztu z sosem } \\
\text { mascotte } \\
\text { Fileciki sauté z „szampionami” } \\
\text { (pieczarkami) } \\
\text { Tort z bita śmietana } \\
\text { à la „Polonia” } \\
\text { Mokka } \\
\text { Likiery }\end{array}$ \\
\hline $\begin{array}{l}3 \text { VIII } \\
1929^{45}\end{array}$ & $\begin{array}{l}\text { Raut z okazji pobytu } \\
\text { Korpusu Oficerskiego } \\
\text { i kadetów włoskiej } \\
\text { Wyższej Szkoły } \\
\text { Marynarki Wojennej } \\
\text { w Livorno, o godz. } 22.00 \\
\text { w salach ratusza }\end{array}$ & $\begin{array}{l}\text { Około } 120 \text { osób, w salach } \\
\text { ratusza, strój wizytowy, } \\
\text { zakąski przygotowała } \\
\text { Piwnica Ratuszowa }\end{array}$ & $\begin{array}{l}\text { Zimny bufet i alkohol } \\
250 \text { ciast } \\
12 \text { tortów }\end{array}$ \\
\hline $\begin{array}{l}4 \text { VIII } \\
1929^{46}\end{array}$ & $\begin{array}{l}\text { Obiad z okazji wizyty } \\
\text { przedstawicieli prasy } \\
\text { jugosłowiańskiej }\end{array}$ & $\begin{array}{l}\text { Około } 20 \text { osób, } \\
\text { przygotowała restauracja } \\
\text { hotelu Polonia }\end{array}$ & $\begin{array}{l}\text { Wódki, zakaski } \\
\text { Barszcz z pasztecikami } \\
\text { Sandacz po parysku } \\
\text { Kurczęta sauté i kompot } \\
\text { francuski } \\
\text { Galaretka z białego wina } \\
\text { à la „Polonia” } \\
\text { Kawa } \\
\text { Likiery }\end{array}$ \\
\hline
\end{tabular}

${ }^{41}$ APP, AmP, 2465, Wycieczka korespondentów pism zagranicznych, 30 VI 1929.

${ }^{42}$ Raki należało $\mathrm{w}$ całości ugotować, następnie utłuc razem ze skorupkami w moździerzu i smażyć z masłem i koperkiem, dodać bulion i śmietanę, a następnie przecedzić. M. Norkowska, op. cit., s. 36.

${ }^{43}$ APP, AmP, 2466, Zjazd Chemików Polskich, 4 VII 1929.

${ }_{44}$ APP, AmP, 2456, Kongresy i zjazdy, k. 317.

${ }^{45}$ APP, AmP, 2470, Wycieczka Korpusu Oficerskiego i Kadetów Włoskiej Szkoły Marynarki Wojennej z Livorno.

${ }^{46}$ APP, AmP, 2456, Kongresy i zjazdy, k. 263. 


\begin{tabular}{|c|c|c|c|}
\hline Data & Przyjęcie & Szczegóły & Menu \\
\hline $\begin{array}{l}6 \text { VIII } \\
1929^{47}\end{array}$ & $\begin{array}{l}\text { Obiad na cześć } \\
\text { rumuńskiego ministra } \\
\text { przemysłu i handlu } \\
\text { Virgila Madgearu oraz } \\
\text { ministra przemysłu } \\
\text { i handlu Eugeniusza } \\
\text { Kwiatkowskiego, } \\
\text { o godz. } 20.00\end{array}$ & $\begin{array}{l}\text { Przyjęcie na ok. } 45 \text { osób, } \\
\text { w Sali Złotej ratusza, } \\
\text { strój: frak i ordery, menu } \\
\text { z Piwnicy Ratuszowej }\end{array}$ & $\begin{array}{l}\text { Zakaski i wódki } \\
\text { Rosół pomidorowy, diablotki } \\
\text { Łosoś z wody ze świeżym } \\
\text { masłem } \\
\text { Pieczeń sarnia, sos } \\
\text { kumberlandzki }^{48} \text {, sałata } \\
\text { zielona i kompot } \\
\text { Parfait }{ }^{49} \text { ananasowy } \\
\text { Kawa }\end{array}$ \\
\hline $\begin{array}{l}28 \text { VIII } \\
1929^{50}\end{array}$ & $\begin{array}{l}\text { Śniadanie z okazji } \\
\text { przyjazdu posłów } \\
\text { francuskich, o godz. } \\
13.00\end{array}$ & $\begin{array}{l}\text { Przyjęcie w Sali Złotej } \\
\text { ratusza na ok. } 90 \text { osób, } \\
\text { obowiazzywał strój } \\
\text { wizytowy, przygotowała } \\
\text { Piwnica Ratuszowa }\end{array}$ & $\begin{array}{l}\text { Zupa żółwiowa }{ }^{51} \\
\text { Sandacz Margarettes } \\
\text { Bukiet jarzyn } \\
\text { Pieczeń sarnia, sos } \\
\text { kumberlandzki (cumberland), } \\
\text { sałata zielona i kompot } \\
\text { mieszany } \\
\text { Bomba brzoskwiniowa } \\
\text { Kawa } \\
\text { Tokaj }\end{array}$ \\
\hline $\begin{array}{l}7 \text { IX } \\
1929^{52}\end{array}$ & $\begin{array}{l}\text { Raut z okazji } \\
\text { VII Zjazdu Lekarzy } \\
\text { i działaczy sanitarnych } \\
\text { samorządowych, o godz. } \\
21.00\end{array}$ & $\begin{array}{l}\text { Przyjęcie na ok. } 200 \text { osób } \\
\text { w salach ratusza, strój } \\
\text { wieczorowy, zakaski } \\
\text { przygotowała Piwnica } \\
\text { Ratuszowa }\end{array}$ & $\begin{array}{l}\text { Specjał krotoszyński } \\
\text { Jasne piwo Huggera } \\
\text { Herbata } \\
\text { Lemoniada cytrynowa } \\
\text { Kawa biała i czarna } \\
\text { Kanapki (na każdym stole } \\
1 \text { półmisek) } \\
200 \text { ciastek i } 12 \text { tortów } \\
\text { owocowych z cukierni } \\
\text { Fangrata } \\
10 \text { małych zestawów } \\
\text { herbatników } \\
\text { Koniak } 5 \text {-gwiazdkowy } \\
\text { Kantorowicza } \\
\text { Woda sodowa }\end{array}$ \\
\hline
\end{tabular}

Źródło: opracowanie własne.

Zaprezentowane powyżej informacje to tylko wycinek tego, co miało miejsce w Poznaniu od połowy maja do końca września 1929 r. Dokumenty, które pozostały po organizacji Pewuki, potwierdzaja, że wydanych przez prezydenta miasta Poznania przyjęć było dużo więcej.

${ }^{47}$ APP, AmP, 2471, Przyjęcie Ministra Przemysłu i Handlu Rumunii, 6 VIII 1929.

${ }^{48}$ Wykwintny zimny sos, który robi się, gotując razem galaretkę porzeczkowa, maderę, tartą cebulę, skórkę i sok z cytryny oraz pomarańczy, paprykę, imbir i musztardę.

${ }^{49}$ Mrożony deser na bazie masy mleczno-jajecznej z bitą śmietaną.

${ }^{50}$ APP, AmP, 2475, Przyjęcie posłów francuskich, 28 VIII 1929.

51 Zupę przyrządzano na bulionie z żółwia z dodatkiem krwi, madery i pokrojonym w paseczki mięsem z żółwia, pieczarkami i białkiem ugotowanym na twardo. Gdy nie można było ugotować zupy z żywego żółwia, kupowano puszki z mięsem żółwiowym w galarecie. M. Norkowska, op. cit., s. 38.

${ }^{52}$ APP, AmP, 2476, VII Zjazd lekarzy i działaczy sanitarnych samorządowych, 7-9 IX 1929. 
Wzmianki o zimnym bufecie, jaki przygotowywano na rautach lub przed głównymi daniami na śniadaniach (mniej obfity niż w trakcie rautu), również pojawiają się $\mathrm{w}$ dokumentach. Za każdy razem był nieco inny, mniej lub bardziej wyszukany. Z okazji przyjęcia zagranicznych ministrów (z Francji, Czechosłowacji, Łotwy, Finlandii, Syjamu, Włoch, Norwegii, Jugosławii) 12 września podczas rautu na stołach znajdowały się m.in. bułki, chleb, jajka, masło, comber cielęcy, sarni, polędwica, wątróbka, szynka gotowana, szczupak, węgorz, sandacz, raki, węgorz wędzony, łosoś, sardynki, ementaler, ser szwajcarski, ser edamski, słonina, kuropatwy, kurczaki, pulardy, kaczki, warzywa i owoce, trufle, kapary, ogórki kiszone, matiasy, bigos, kawa, herbata, 120 ciast, 7 tortów, madera, koniak, czerwone wino, wódka, specjał krotoszyński, jasne piwo Huggera, woda sodowa ${ }^{53}$.

Wyjątkowym wydarzeniem była „herbatka” zorganizowana podczas II Narodowego Zlotu Harcerzy. Na 16 lipca na godz. 17.30 prezydent Ratajski zaprosił 120 osób (ok. 40 osób spośród wojskowych, zasłużonych osób dla Poznania i pracujących przy wystawie oraz ok. 80 osób spośród reprezentacji harcerzy) do ratusza, gdzie podano kawę, herbatę, 12 tortów, ciasta owocowe i herbatniki, truskawki z bita śmietaną i czereśnie z cukierni Fangrata ${ }^{54}$.

W Poznaniu na przełomie XIX i XX w. w eleganckich restauracjach serwowano potrawy kuchni polskiej i europejskiej. Dania wymienione w jadłospisach podawano już 30 lat wcześniej, więc zupa żółwiowa, rakowa, comber sarni, ryby czy sos kumberlandzki ${ }^{55}$ nie stanowiły nowinek, a raczej część znanej panoramy kulinarnej miasta. Podobnie zreszta typowy był układ posiłku, czyli trzy dania, na które składała się zupa, danie średnie z jarzynami i warzywami oraz danie główne, czyli pieczyste $z$ kompotem ${ }^{56}$. Na pewno część potraw znano w innych krajach europejskich, więc z jednej strony na oficjalnym przyjęciu goście mogli spożyć coś, co nie było im obce, z drugiej jednak spróbować potraw typowych dla kuchni polskiej, czerpiącej jeszcze cały czas z tradycji ziemiańskich, i oczywiście polskich, szczególnie lokalnych alkoholi.

Uroczysta okazja - śniadanie czy obiad - dawała dużo możliwości wykazania się kunsztem kulinarnym, którego wymagała obecność znakomitych osób. Pojawienie się na stole ryb, takich jak sandacz, łosoś, lin, dzikich mięs, np. sarniny, faszerowanych kurcząt, zup: rakowej czy żółwiowej świadczy o wielkich staraniach $\mathrm{w}$ doborze menu i chęci przypodobania się gościom, były to bowiem najbardziej wówczas cenione dania ${ }^{57}$. Warto zwrócić uwagę na częste serwowanie ryb podczas przyjęć. Ich konsumpcja w Polsce nie była wówczas duża i obawiano się, czy wystarczy ich dla gości z zagranicy, którzy

\footnotetext{
53 APP, AmP, 2477, Przyjęcie Ministrów Zagranicznych, 12 IX 1929.

${ }_{54}$ APP, AmP, 2468, Zlot Narodowy Harcerzy, 13 VII 1929.

${ }_{55}$ Por. W. Karolczak, Coś dla podniebienia..., s. 154-163.

${ }^{56}$ Ibidem, s. 162.

${ }^{57}$ M. i J. Łozińscy, Historia polskiego smaku. Kuchnia, stót, obyczaje, Warszawa 2013, s. $225,228$.
} 
przyzwyczajeni byli „do lepszego jedzenia”58. Próbowano nawet zapewnić sobie dostawę szlachetniejszych gatunków, jak np. sandacz, z zagranicy Niemiec i Łotwy. Okazało się jednak, że miejscowa produkcja wystarczyła ${ }^{59}$. Poza rybami za ekskluzywny produkt można uznać również szparagi, które rozpowszechniły się w XIX w., ale były przeznaczone dla zamożnych stołów ${ }^{60}$.

Nigdzie w opiniach zagranicznych gości nie znajdujemy informacji, jak odbierali poczęstunek, niemniej jednak Lionel Amistié - sekretarz ministra przemysłu i handlu Georges'a Bonnefousa w liście do prezydenta Ratajskiego wspominał serdeczność, z jaką zostali przyjęci ${ }^{61}$. Podobne wrażenia odnieśli parlamentarzyści francuscy, którzy byli wzruszeni „grzecznością i gościnnościa Prezydenta Ratajskiego oraz dra Wachowiaka"62. Spotkania przy stole przyczyniały się do zacieśniania relacji, co odnotowano przy okazji śniadania na cześć ministra Bonnefousa i ambasadora Francji Jules'a Laroche’a, pisząc, że „pogłębiło serdeczny nastrój” oraz że „pobyt ten we wszystkich szczegółach był manifestacją na rzecz przyjaźni polsko-francuskiej”'63. Można pokusić się więc o stwierdzenie, że kuchnia stawała się elementem propagandy na rzecz Polski.

Oczywiście władze miasta i zarząd wystawy również brali udział w rozmaitych przyjęciach, często niemal dzień po dniu. Dzięki zachowanym zaproszeniom możemy zorientować się, gdzie miały one miejsce. Zapraszającymi byli także organizatorzy wycieczki. Często wybierano restaurację hotelu Bazar, restaurację targowa Belweder, restaurację hotelu Polonia lub Dwór Huggera, ewentualnie Palais Royal przy pl. Wolności. 17 maja o godz. 14.00 miało odbyć się $\mathrm{w}$ Bazarze śniadanie z okazji otwarcia wystawy, nie wiadomo jednak dla kogo. Z planu pobytu prezydenta Ignacego Mościckiego, otwierajacego przecież Pewukę, wynika, że tego dnia był na zawodach hippicznych ${ }^{64}$. W Bazarze, prawdopodobnie w Sali Białej, Seweryn Samulski, kierujaccy działem przemysłowym wystawy, przyjął na śniadaniu przemysłowców francuskich ${ }^{65}$, a minister Karol Bertoni wydał bankiet dla Węgierskiego Związku Narodowego ${ }^{66}$. W Belwederze zorganizowano z kolei bankiet na blisko 140 osób z okazji Zlotu Sokolstwa Polskiego. Nie wiadomo, co podawano, ale zachował się rachunek,

${ }_{58}$ Sprawozdanie Izby Przemystowo-Handlowej w Poznaniu za rok 1929, Poznań 1930, s. 191.

${ }^{59}$ Ibidem.

${ }^{60}$ M. Toussaint-Samat, Historia naturalna $i$ moralna jedzenia, Warszawa 2002, s. 632-633.

${ }^{61}$ APP, AmP, 2477, Przyjęcie Ministrów Zagranicznych, 3 X 1929.

62 „Echo Powszechnej Wystawy Krajowej”, 1 X 1929, s. 424.

${ }^{63}$ Ibidem. Do wizyt Francuzów przywiązywano dużą wagę. Z jednej strony bowiem Polska w kwietniu 1929 r. podpisała umowę gospodarczą dotyczącą wymiany towarów z Francja, po drugie upatrywano w niej najważniejszego sojusznika i Polsce najżyczliwszego.

${ }_{64}$ APP, AmP, 2460, Przyjazd Prezydenta Rzeczypospolitej i Otwarcie PWK, szczegółowy program pobytu Prezydenta Rzeczypospolitej w Poznaniu.

${ }_{65}$ APP, AmP, 2461, Wycieczka przemysłowców francuskich, 11 VI 1929, program pobytu oficjalnej wycieczki przemysłowców francuskich pod przewodnictwem ambasadora Noulensa.

66 APP, AmP, 2479, Programy dotyczące uroczystości i przyjęć w czasie PWK, program wycieczki Węgierskiego Związku Narodowego, 
który opiewał na 5520 zł, a więc 40 zł za osobę ${ }^{67}$. Podobne lokale wybierano, gdy zapraszającym na śniadanie lub obiad nie był prezydent Ratajski, ale np. Izba Przemysłowo-Handlowa czy różne komitety lub związki zawodowe, albo nawet kierownictwo wystawy czy sam minister Kwiatkowski. Bardzo często podczas pobytu danej wycieczki nie ograniczano się do jednego lokalu, ale za każdym razem jedzono gdzie indziej. Podyktowane było to rozkładem dnia. Przykład stanowi wycieczka dziennikarzy monachijskich, którzy 6 sierpnia we wtorek jedli śniadanie we Dworze Huggera, co zrozumiałe, ponieważ cały dzień spędzili na terenach wystawowych. Następnego dnia rano zwiedzali Pałac Rządowy, ale śniadanie było w Palais Royal z uwagi na późniejsze oglądanie miasta. W czwartek 8 sierpnia zwiedzano rano wystawę rolnicza i o 13.00 zjedzono śniadanie w Bazarze, z kolei w piątek, ostatniego dnia pobytu w Poznaniu, dziennikarze odwiedzili Pałac Sztuki i udali się tuż obok do Polonii, gdzie zreszta byli zakwaterowani, na śniadanie, po czym wyjechali do Warszawy ${ }^{68}$.

16 maja we Dworze Huggera o 14.00 w Sali Reprezentacyjnej wydano uroczyste śniadanie na cześć prezydenta Mościckiego z okazji otwarcia Pewuki69. Zachowało się wspomnienie bankietu w raporcie Laroche’a, ambasadora Francji w Warszawie, który napisał: „Po dwóch godzinach [po inauguracji wystawy] odbył się bankiet na 780 osób, w jednej z restauracji wystawowych, bardzo dobrze zorganizowany, bardzo dobrze i bardzo szybko podany"

Nie wiadomo niestety, co serwowano ani z jakim odbiorem spotkały się same potrawy. Zachowały się jednak dwa jadłospisy ze Dworu Huggera, które daja przynajmniej niewielki obraz tego, co w tamtym czasie oferowała restauracja. Podczas zjazdu Polaków z zagranicy minister Bertoni wydał tam śniadanie 19 lipca, na którym podano zakaski, krem z raków z diablotkami, majonez z sandacza, polędwicę z rożna z jarzynami, na deser - parfait (mrożony mus) z malin i kawę ${ }^{71}$. Dzień później śniadanie wydał z kolei prezydent Ratajski. Tym razem we Dworze Huggera podano krem Dubarry ${ }^{72}$, mostki wołowe z sosem chrzanowym, kurczęta z sałata, lody i kawę ${ }^{73}$.

Trudno obliczyć, ile było oficjalnych śniadań, obiadów i rautów w czasie wystawy. Na podstawie programów uroczystości można stwierdzić, że oprócz

${ }^{67}$ APP, AmP, 2464, Zlot Sokolstwa Polskiego, 28-30 VI, 2 VII 1929. Była to wysoka cena, biorąc pod uwagę, że kilogram chleba kosztował wówczas niewiele ponad 40 gr. S. Waschko, op. cit., s. 289.

${ }^{68}$ APP, AmP, 2479, Programy dotyczące uroczystości i przyjęć w czasie PWK, program wycieczki dziennikarzy monachijskich.

${ }^{69}$ APP, AmP, 2460, Przyjazd Prezydenta Rzpl i Otwarcie PWK, 17 V 1929.

70 Archives de Ministère des Affaires Etrangères à La Courneuve (AMAE), Europe 1930-1940, Pologne 250 B, L’Ambassadeur de France en Pologne à Son Excellence Monsieur Le Ministre des Affaires Etrangères à Paris, 25 V 1929.

${ }^{71}$ APP, AmP, 2467, Zjazd Polaków z Zagranicy, 19 VII 1929, k. 38.

${ }^{72}$ Zupa krem z kalafiora i pora, na bulionie, ze śmietana, masłem i mąka.

${ }^{73}$ APP, AmP, 2467, Zjazd Polaków z Zagranicy, 20 VII 1929, k. 41. 
tych już wymienionych wiele mogło odbywać się np. w sierpniu, kiedy przybywało czasami kilka wycieczek dziennie i niemal każdego dnia.

Nie sposób nie zgodzić się, że organizatorzy dobrze zadbali o aprowizację dla gości zarówno o bardziej, jak i mniej zasobnych portfelach. Z publikacji powystawowej wynika jednak, że nie wszystkie lokale przynosiły duże zyski, niektóre wręcz - jak Dwór Huggera - wykazywały deficyt. Przyczyny być może należy upatrywać $\mathrm{w}$ fakcie, że najczęściej korzystano z niedrogich lokali, a oficjalne przyjęcia, mimo iż częste, odbywające się w eleganckich miejscach, nie równoważyły poniesionych na ich budowę kosztów. Podobnie poznańskie restauracje niekoniecznie notowały wzrost zysków, ponieważ na czas Pewuki traciły stałych klientów, w miejsce których pojawiali się turyści. Nie wiadomo dokładnie, co znajdowało się w menu restauracji w centrum Poznania i tych wystawowych, można się jedynie domyślać na podstawie jadłospisów przygotowanych przez Piwnicę Ratuszowa, że pewne dania się powtarzały, ale działo się to raczej w droższych lokalach. Był to czas, kiedy w kuchni polskiej następował zwrot w kierunku lżejszego sposobu gotowania - więcej warzyw i owoców, a mniej śmietany i masła, co też widać w proponowanych daniach. Warto mieć na uwadze, że materiał źródłowy, jaki został po tym okresie, ukazuje, co jadano w poznańskich restauracjach w latach dwudziestych w ogóle, nie tylko przecież podczas wystawy. Oficjalne przyjęcia były ważną częścia Pewuki, stanowiły bowiem w pewnym sensie wizytówkę miasta i Magistratu, które z pewnością nie miały się czego wstydzić przed zagranicznymi gośćmi, a poza tym miały pokazać zamożność stolicy Wielkopolski i pewnie całego kraju.

\section{Streszczenie}

W 1929 r. urządzono w Poznaniu Powszechną Wystawę Krajowa, która miała pokazać dorobek odrodzonej Polski. Zlokalizowana była na terenach obecnych Targów Poznańskich, parku Wilsona oraz części dzielnic Grunwald i Łazarz. Teren „A” poświęcono głównym gałęziom przemysłu, takim jak włókiennictwo czy przemysł ciężki, na terenie „B” prezentowano osiąnięcia sztuki i polskiego rządu, teren „C” był częścią rekreacyjna, na terenie „D” ulokowano bazary, a w części „E” skupiono pawilony pozostałych gałęzi drobnego przemysłu oraz rolnictwa. Przez ponad cztery miesiące trwania wystawy Poznań odwiedzały liczne wycieczki krajowe i zagraniczne oraz organizowano wiele kongresów i zjazdów. Z uwagi na brak badań dotyczących skutków Pewuki trudno ją dzisiaj należycie ocenić.

Obecność tak wielu gości wymagała odpowiedniej aprowizacji. W Poznaniu powstawały nowe restauracje, a już istniejące cieszyły się dużym powodzeniem. Odwiedzano szczególnie kawiarnie Dobskiego, Fangrata, restaurację Palais Royal, Grand Café czy Bazar. Ustalono nawet odpowiedni cennik, jaki powinien obowiązywać w lokalach,. Również na terenach wystawy można było się posilić, m.in. we Dworze Huggera, który stanowił centralną restaurację wystawowa, Belwederze, Dancingu oraz mniejszych bufetach i kawiarniach. Ceny dostosowano zarówno do mniej, jak i bardziej zamożnych gości.

Obecność oficjalnych wycieczek z kraju i ze świata (polityków, dziennikarzy, przedsiębiorców) wymagała odpowiedniego przyjęcia ich przez władze miasta, które również chciały się jak najlepiej zaprezentować. Prezydent Poznania Cyryl Ratajski wydał podczas Pewuki wiele przyjęć, które odbywały się najczęściej w Sali Złotej poznańskiego ratusza. 
Były to śniadania, obiady i rauty, organizowane według zasad protokołu dyplomatycznego. Serwowano podczas nich dania kuchni polskiej i europejskiej, przygotowywane zazwyczaj przez Piwnicę Ratuszową - restaurację mieszczącą się w przyziemiach ratusza. Posiłek zwykle składał się z zupy, dwóch dań głównych, deseru oraz kawy. Dodatkowo podawano zakąski i alkohol. Menu był wykwintne i zazwyczaj sięgano po klasyczne, choć lekkie dania. Dokumenty z Archiwum Państwowego w Poznaniu zawierają jadłospisy z przyjęć w ratuszu i pozwalają odkryć, co konkretnie wówczas serwowano. Na uroczysty posiłek rozsyłano specjalne zaproszenia, wymagano także oficjalnego stroju. Magistrat planował, kto ma pełnić służbę oraz jak należy usadzić gości. $\mathrm{Na}$ tę okazję wyciagano specjalną zastawę z herbem miasta Poznania i zamawiano orkiestrę do przygrywania. Proszono również dyrekcję ogrodów miejskich o odpowiednią dekorację sali kwiatami.

Oczywiście członkowie Magistratu również byli zapraszani na przyjęcia wydawane przez członków rządu, dziennikarzy czy przedsiębiorców, którzy podejmowali gości wystawowych. Zachowane menu prezentują ówczesną kuchnię polską czerpiąca z tradycji, lokalnych zwyczajów oraz europejskich standardów. Zagraniczni goście bardzo dobrze wspominali pobyt w Poznaniu i przyjęcie przez władze miasta, które chciały pokazać się z jak najlepszej strony.

\section{Breakfast with Mayor Ratajski, or What and Where Was Eaten during the Universal National Exhibition in Poznań}

In 1929, the Universal National Exhibition was organized in Poznań, which was to show the achievements of reborn Poland. It was located in the area of the present Poznan Fair, Wilson Park and parts of the Grunwald and Eazarz districts. The "A" area was devoted to major industries such as textiles and heavy industry, the "B" area presented works of art and achievements of the Polish government, the " $C$ " area was a recreational field, the "D" area housed various bazaars, and the "E" area was reserved for pavilions of other branches of small industry and agriculture. For over four months of the Exhibition, Poznan was visited by numerous domestic and foreign groups of people and held numerous congresses and conventions. Due to the lack of research on the effects of the Exhibition, it is difficult to assess it properly today.

The presence of so many guests required adequate provisioning. New restaurants were established in the city, and previously existing ones enjoyed great popularity. Such coffeehouses as those of Dobski, and Fangrat, and restaurants "Palais Royal," "Grand Café," and "Bazar" were particularly visited. An appropriate price list was also set for all kinds of restaurants to prevent price increases. Also in the exhibition area there were many places where people could eat, including "Hugger Manor," which was the central restaurant of the Exhibition, and also "Belvedere," "Dancing" and smaller buffets and cafeterias. Prices were adjusted to both less and more affluent guests.

The presence of official visitors from the country and the world (politicians, journalists, entrepreneurs) required proper reception by the city authorities, who also wanted to present themselves as well as possible. The Mayor of Poznań, Cyril Ratajski, gave many receptions during the Exhibition, which were most often held in the Golden Hall of the Poznan City Hall. They were breakfasts, dinners and banquets organized according to the principles of the diplomatic protocol. Polish and European dishes were served, usually prepared by the "Town Hall Cellar" - a restaurant located in the town hall's basement. The meal usually consisted of soup, two main dishes, dessert and coffee. In addition, appetizers and alcohol were served. The menu was exquisite and usually included classic, though light dishes. Documents from the State Archives in Poznań contain menus from parties at the town hall and make it possible to discover what was served at that time. Special invitations were sent to the celebratory meal, and formal attire was required. The Town Hall planned who should perform the 
service and how to seat the guests. For this occasion, special tableware was pulled out with the coat of arms of the city of Poznan and an orchestra played music during the meal. The management of the City Gardens was also asked to properly decorate the room with flowers.

Of course, members of the City Hall were also invited to parties hold by members of the government, journalists or entrepreneurs who hosted exhibition guests. The preserved menus testify to the Polish cuisine of that time, drawing on tradition, local customs and European standards. Foreign guests very well remembered their stay in Poznan and the reception by the city authorities who wanted to show their best side.

\section{Bibliografia}

Czarnecki W., To byt też mój Poznań. Wspomnienia architekta miejskiego z lat 1925-1939, wybór i oprac. J. Dembski, Poznań 1987.

Danielewski B., Pewuka, w: Poznańskie wspominki z lat 1918-1939, red. T. Kraszewski, T. Świtała, Poznań 1973, s. 151-164.

Karolczak W., Coś dla podniebienia, czyli specjalności kulinarne w lokalach poznańskich na przełomie XIX i XX wieku, „Kronika Miasta Poznania «Do stołu podano»” 2003, nr 4, s. $149-164$.

Karolczak W., Spacerkiem po Plajcie, „Kronika Miasta Poznania «Plac Wolności»” 2014, nr 4, s. 41-62.

Kempisty Ł., Przedsiębiorstwa, w: Powszechna Wystawa Krajowa w Poznaniu w roku 1929. Dzieto zbiorowe pod kierownictwem dr. Stanistawa Wachowiaka prezesa Zarzadu P.W.K., t. II, Poznań 1930, s. 203-233.

Leitgeber S., Rauty u prezydenta, „Kronika Miasta Poznania” 1996, nr 4, s. 108-117.

Litewka P., Powszechna Wystawa Krajowa, część pierwsza (16 maja - 30 września 1929), „Kronika Miasta Poznania” 1979, nr 2, s. 37-53.

Litewka P., Powszechna Wystawa Krajowa (16 maja - 30 września 1929). Dokończenie, „Kronika Miasta Poznania” 1979, nr 3, s. 5-24.

Łozińscy M. i J., Historia polskiego smaku. Kuchnia, stót, obyczaje, Warszawa 2013.

Łozińska M., Smaki dwudziestolecia. Zwyczaje kulinarne, bale i bankiety, Warszawa 2011. Norkowska M., Najnowsza kuchnia wytworna i gospodarska, Warszawa-Kraków 1903.

Poznań w roku Powszechnej Wystawy Krajowej. Przewodnik po mieście, jego zabytkach i muzeach z trójbarwnym planem miasta i 15 ilustracjami, oprac. H. Szczerbowski, Poznań 1929.

Przewodnik po Wystawie. Powszechna Wystawa Krajowa w 1929 roku w Poznaniu, Poznań 1929.

Skałkowski A.M., Bazar w nowej Polsce (1921-1938), „Kronika Miasta Poznania «Bazar»” 2008, nr 2, s. 43-62.

Waschko S., Aprowizacja na P.W.K., w: Powszechna Wystawa Krajowa w Poznaniu w roku 1929. Dzieto zbiorowe pod kierownictwem dr. Stanistawa Wachowiaka prezesa Zarzadu P.W.K., t. II, Poznań 1930, s. 285-296.

Biog r a m: Magdalena Heruday-Kiełczewska - dr; adiunkt w Zakładzie Archiwistyki Instytutu Historii Uniwersytetu im. Adama Mickiewicza. Zajmuje się metodyką archiwalna, dziejami Poznania oraz relacjami polsko-francuskimi. Autorka książek: Reakcja Francji na wprowadzenie stanu wojennego w Polsce: grudzień 1981 - styczeń 1982 (2012); Inventaire des Archives de l'Association Solidarité France Pologne 1980-2004. Inventarz Archiwum Stowarzyszenia Solidarité France Pologne 1980-2004 [par M. Heruday-Kiełczewska] (2013); „Solidarność” nad Sekwana. Działalność Komitetu Koordynacyjnego NSZZ „Solidarność” w Paryżu 1981-1989 (2016). E-m a il: mh4965@amu.edu.pl. 